Original Investigation

\title{
Translation and Validation of Chronic Otitis Media Benefit Inventory (COMBI) in Turkish Language
}

\author{
Hakan $\operatorname{Kara}^{1}$ (D), Can Doruk ${ }^{1}$ (D), Mehmet Çelik ${ }^{1}$ (D), Beldan Polat ${ }^{1}$ (D), Vedat Topsakal ${ }^{2}$, \\ Kadir Serkan Orhan ${ }^{1}$ (it) \\ ${ }^{1}$ Department of Otolaryngology - Head and Neck Surgery, İstanbul University, İstanbul School of Medicine, İstanbul, Turkey \\ ${ }^{2}$ Department of Otolaryngology - Head and Neck Surgery, Universitair Ziekenhuis Antwerpen, Antwerp, Belgium
}

\begin{abstract}
Objective: The aim of this study was to translate the Chronic Otitis Media Benefit Inventory (COMBI) into Turkish and evaluate the questionnaire's reliability in assessing benefit outcomes in patients after ear surgery.

Methods: A total of 30 patients with chronic otitis media who underwent ear surgery were asked to fill out the translated Turkish version of the COMBI questionnaire six months after their surgery twice, 10 days apart. The patients were divided into two groups in two different ways based on surgical and audiological outcomes. These were surgical success (SS), surgical failure (SF), audiological success (AS), audiological failure (AF) groups. Student's $-t$ test was performed to show the differences in the COMBI scores of the groups. Cronbach's alpha value was calculated to test internal consistency, Pearson's correlation coef-
\end{abstract}

ORCID IDs of the authors: H.K. 0000-0003-3079-6866; C.D. 0000-0002-4983-3666; M.C. $0000-0003-3575-9167 ;$ B.P. 0000-0002-7908-8329; V.T. 0000-0003-0416-4005; K.S.0. 0000-0002-5125-2035.

Cite this article as: Kara H, Doruk C, Celik M, Polat B, Topsakal V, Orhan KS. Translation and Validation of Chronic Otitis Media Benefit Inventory (COMBI) in Turkish Language. Turk Arch Otorhinolaryngol 2020; 58(1):24-9.

\section{Corresponding Author:}

Hakan Kara, dr.hakankara@hotmail.com

Received Date: 14.08.2019

Accepted Date: 01.12 .2019

Content of this journal is licensed under a Creative Commons Attribution 4.0 International License. Available online at www.turkarchotolaryngol.net

\section{Introduction}

Chronic otitis media (COM) is a common health problem with a prevalence of $<1 \%$ in high-income countries to up to $4 \%$ in developing countries (1). Along with chronic symptoms of ear drainage and hearing loss, chronic otitis may lead to devastating complications such as meningitis, labyrinthitis, facial nerve paralysis. Furthermore, COM deteriorates the quality of life (QoL) of the patients by affecting their social and work lives. Examples are malodorous ear drainage which causes patients to avoid getting involved in social activities, hearing loss which affects the home and work life of patients.

Measuring the Health-Related Quality of Life (HRQoL) scores of patients using the Patient-Reported Outcome Measures is a rapidly progressive ficient was measured to demonstrate test-retest reliability and factor analysis was run.

Results: The average score of the SS group was 51.08 and significantly higher than the score of the SF group (42.40) ( $\mathrm{p}=0.012)$. There was, however, no statistically significant difference between the average scores of the AS and the AF groups ( $\mathrm{p}=0.330)$. A Cronbach's alpha value of 0.862 was found. Pearson's $r$ value was calculated 0.810 . Factor analysis showed that a three-factor solution explained the $70.2 \%$ of the variance.

Conclusion: The Turkish version of the COMBI is a valid test with high test-retest reliability. It should be used with objective assessment tools for better understanding how patients benefit from the surgery.

Keywords: Otitis media, tympanoplasty, quality of life, reliability and validity, patient health questionnaire field to assess patients' symptoms and to determine personalized treatment (2). There are many QoL questionnaires available to assess $\mathrm{COM}$, such as the Chronic Otitis Media Outcome Test-15 (3), the Chronic Otitis Media-5 (4) questionnaire, and the newest Chronic Otitis Media Questionnaire-12 (COMQ-12) developed by Phillips et al.(5).

Chronic Otitis Media Benefit Inventory (COM$\mathrm{BI}$ ) is recently developed by Phillips et al. (6) to assess the changes in patient's symptoms with treatment. Information about how patient's quality of life measures are affected by surgical intervention can be determined with COMBI.

The aim of this study was to translate the COMBI into Turkish, evaluate the internal consistency, the 
test-retest reliability of the test, and to validate the adaptation to Turkish language for further use in studies.

\section{Methods}

Ethics Committee Approval for the study was taken from İstanbul University School of Medicine Ethics Committee for Scientific Research with file number 2019/50.

\section{Study Design}

Thirty patients that were older than 18 years of age, had COM and underwent ear surgery were enrolled in our prospective study. After a 6-month waiting period, which is considered to be the recovery period after surgical intervention, all patients were requested to fill out the COMBI questionnaire twice, 10 days apart. We excluded the patients who were not able to give their informed consent. Also, patients who had prior tympanoplasty or mastoidectomy were excluded from the study.

\section{COMBI Questionnaire}

The COMBI questionnaire contains 12 items that dynamically assesses the changes in the severity and the frequency of the symptoms and the QoL of the patients who underwent ear surgery for COM. The 5-point Likert scale was used to score each question in a descending order from 5 (much better) to 1 (much worse).

These 12 items were constructed by Phillips at al. (5) from the static assessment tool COMQ-12 which was translated into Turkish and validated in our previous study (7).

The first 7 items of the questionnaire inquire about the changes in the ear symptoms following surgical intervention. The next four items assess the effects of surgery on lifestyle, work and the use of healthcare services of the patient. The last item evaluates the changes in the overall well-being of the patients after the operation.

\section{Translation and Back-Translation}

An official permission was obtained from the main author to translate and validate the Turkish version of the COMBI questionnaire. Then, the COMBI was translated into Turkish by the second author and checked by the senior authors. Turkish questions were back-translated into English by a native English speaker after some adjustments were made. No differences were observed between the two versions of the questionnaire; hence, the adaptation was verified.

\section{Subjects}

Thirty COM patients that underwent ear surgery were enrolled in the study. All patients were native-Turkish speakers older than 18 years of age and operated on by the first two and the fourth authors. Patients who were able to give their informed consent for the study were asked to fill out the COMBI at the $6^{\text {th }}$ month follow-up visit after their surgery. To understand test-retest reliability patients were asked to complete the questionnaire for a second time 10 days after their first responses.

Additional information about the study group were collected. These were demographic data of patients, otoscopic examination and pure-tone audiometry (PTA) (average of 0.5,2.0,4.0 kHz) status of the ears prior to and six months after the surgery and the type of surgery done.

Otoscopic findings prior to the surgery were classified into 5 groups: $<1 / 4$ dry perforation, $>1 / 4$ dry perforation, visible cholesteatoma $(\mathrm{VC})$, retraction pocket without visible cholesteatoma (RPWVC) and wet ear.

Otoscopic findings after six months of the surgery were classified into 5 groups: 1) Intact tympanic membrane for tympanoplasty and dry cavity without recurrence of cholesteatoma for mastoidectomy was defined as "normal," 2) $<1 / 4$ dry perforation 3) $>1 / 4$ dry perforation, 4) wet ear and 5) recurrence of cholesteatoma. Cases that did not fall under the "normal" definition at the postoperative $6^{\text {th }}$ month were included in the surgical failure (SF) group, and patients with "normal" otoscopic results were included in the surgical success (SS) group.

Pre-and post-operative PTA were performed in all patients. Air and bone conduction $(\mathrm{AC}, \mathrm{BC})$ thresholds and air-bone gap $(\mathrm{ABG})$ were measured. PTA statuses of the relevant ears were classified into two groups: Audiological failure (AF) and audiological success (AS). Achievement of 10 decibels (dB) or more improvement at the average of 0.5, 2.0, 4.0 kilohertz $(\mathrm{kHz})$ on $\mathrm{AC}$ thresholds were classified as AS. A less then $10 \mathrm{~dB}$ decrease in $\mathrm{AC}$ thresholds and any increase in $\mathrm{AC}$ thresholds were classified as AF.

\section{Statistical Analysis}

IBM Statistical Package for the Social Sciences version 22.0 (IBM SPSS Corp.; Armonk, NY, USA) was used to perform the statistical analysis. A value of $\mathrm{p}<0.05$ was considered statistically significant. Seven different tests were used:

1- Descriptive analysis was made to report demographic data.

2- Measurement of skewness and the Shapiro-Wilk test were used to evaluate the normality of the data.

3- Parametric independent-samples t-test was used to compare the overall scores of the SF and SS groups and of the AF and AS groups. The validation of the questionnaire was made based on these comparisons.

4- Cronbach's alpha was calculated to assess inter-item correlation and internal consistency of the questionnaire. A coefficient of 0.70 or higher was considered reliable (8).

5- Test-retest reliability was shown by using Pearson's correlation coefficient. Correlation coefficients varied from 0 (no reliability) to 1 (perfect reliability). A value of $>0.7$ was considered acceptable reliability in the literature (9).

6- Kaiser-Meyer-Olkin (KMO) and Bartlett's tests were used to measure the adequacy of sampling for performing factor analysis. A value of $>0.5$ was considered acceptable in line with the literature (10).

7- Factor analysis was performed using principal component extraction with varimax rotation. The factor loading coefficient was measured to show the correlation between the individual item and the underlying factor. 


\section{Results}

A total of 30 patients (19 females, 11 males) completed the COMBI questionnaire and the retest. The mean age of the patients \pm standard deviation $(\mathrm{SD})$ was $36.8 \pm 12.5$ years (range: 18 to 59 years). Descriptive analysis is shown in Table 1 .

Tympanoplasty was performed in 20 patients. Of these, 15 had $>1 / 4$ dry perforation, three had $<1 / 4$ perforation and the remaining two had RPWVC before the surgery. Two of the patients underwent ossicular chain reconstruction (OCR). Tympanostomy tube was inserted in one patient. Four patients were included in the SF group because they had $<1 / 4$ perforation in the $6^{\text {th }}$ month of their operations. Sixteen patients were considered as SS due to normal otoscopy after the surgery. An improvement of $10 \mathrm{~dB}$ or more in $\mathrm{AC}$ thresholds were achieved in 15 patients, and the remaining five patients were included in the AF group.

Canal wall down (CWD) mastoidectomy + tympanoplasty was done in five patients. One of them had wet ear prior to the surgery. One patient had VC. One patient had $>1 / 4$ dry perforation and tympanosclerosis. The remaining two patients had RPWVC. OCR was only performed in the patient with $>1 / 4$ dry perforation and tympanosclerosis. All patients had normal otoscopy after surgery, and they were included in the SS group. Three of five patients showed $10 \mathrm{~dB}$ or more improvement in $\mathrm{AC}$ thresholds and were included in the AS group.

CWD mastoidectomy without tympanoplasty was performed in two patients. Both of these patients had VC prior to surgery. Both of these patients were included in the SS group, but at the same time in the AF group because of their increase in $\mathrm{AC}$ thresholds.

Canal wall up (CWU) mastoidectomy + tympanoplasty was performed in two patients. One had VC. The other had RPWVC and cholesterol granuloma was seen during the operation. Both received OCR. The patient with VC had wet ear six months after the surgery and included in the SF group, but also in the AS group since she had a $15 \mathrm{~dB}$ decrease in $\mathrm{AC}$ threshold. The other patient had normal otoscopy, but a $12 \mathrm{~dB}$ increase in $\mathrm{AC}$ threshold after the surgery and was included in the AF group.
Only one patient who had VC prior to surgery underwent atticotomy + tympanoplasty + OCR. She was included in the SS group since she had no abnormal otoscopic findings, but in the AF group because of an $8 \mathrm{~dB}$ gain in $\mathrm{AC}$ threshold.

As a result, only five patients were evaluated in the SF group and 11 patients in the AF group. Only one patient met the criteria of both surgical and audiological failure (Table 2).

Mean preoperative and postoperative $\mathrm{AC}$ thresholds were $42.6 \pm 17.4 \mathrm{~dB}$ and $30.3 \pm 20.9 \mathrm{~dB}$, respectively. While mean $\mathrm{ABG}$ prior to surgery was $30.4 \pm 9.05$, it was $18.03 \pm 14.2$ after the 6-month recovery period.

Average scores for the first test and the retest of the COMBI questionnaire were $49.6 \pm 7.2$ and $50.8 \pm 7.1$, respectively.

The Shapiro-Wilk test was used to assess the distribution of the data. P-values for the overall scores of the first test of COMBI were 0.232 and 0.814 for the SS and the SF groups, respectively. Skew values for the same groups were -0.086 and -0.608 , respectively.

In addition, the p-values for the overall scores of the AS and the AF groups for the first test of COMBI were 0.101 and 0.546 , respectively. Skew values were -0.651 and -0.324 , respectively. Since all p-values were $>0.05$, and all skew values were between +1 and -1 , the distribution of the data was considered as normal. Therefore, parametric tests were chosen for further analysis.

The COMBI score of the SS group $(51.08 \pm 6.35)$ was signifi-

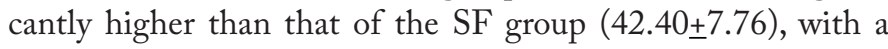
mean difference value of $8.68(\mathrm{p}=0.012)$.

However, there was no statistically significant difference between the COMBI scores of the AS group $(50.63 \pm 8.09)$ and the $\mathrm{AF}$ group (47.91 \pm 5.43$)(\mathrm{p}=0.330)$.

Cronbach's alpha value was 0.862 and since higher than 0.70 , indicated high inter-item correlation and the internal consistency for the questionnaire.

Table 1. Descriptive analysis of COMBI scores, AC thresholds, age and sex of patients

\begin{tabular}{l|c|c|c|c|c}
\hline & Total $(\mathrm{n}=\mathbf{3 0})$ & SS Group $(\mathrm{n}=\mathbf{2 5})$ & SF Group $(\mathrm{n}=\mathbf{5})$ & AS Group $(\mathrm{n}=\mathbf{1 9})$ & AF Group $(\mathrm{n}=\mathbf{1 1})$ \\
\hline COMBI Score & $49.63 \pm 7.25(31-60)$ & $51.08 \pm 6.36(39-60)^{*}$ & $42.4 \pm 7.77(31-51)^{*}$ & $50.63 \pm 8.09(31-60)^{+}$ & $47.91 \pm 5.43(39-55)^{+}$ \\
\hline Preop AC th $(\mathrm{dB})$ & $42.6 \pm 17.4$ & $41.48 \pm 16.63$ & $48.2 \pm 22.11$ & $42.58 \pm 18.97$ & $42.64 \pm 15.17$ \\
\hline Postop AC th $(\mathrm{dB})$ & $30.3 \pm 20.9$ & $30.24 \pm 21.78$ & $30.6 \pm 17.91$ & $22.37 \pm 16.41$ & $44 \pm 21.35$ \\
\hline Age & $36.8(18-59)$ & $34.84(18-59)$ & $47(36-59)$ & $36.42(18-59)$ & $37.64(18-59)$ \\
\hline Sex & & & & 13 & 6 \\
\hline Female & 19 & 14 & 5 & 6 & 5 \\
\hline Male & 11 & 11 & 0 & 6 \\
\hline
\end{tabular}

Data are presented as Mean+Standard deviation (minimum-maximum values).

*p value for difference between groups is 0.012 .

${ }^{+} \mathrm{p}$ value for difference between groups is 0.330 .

SS: surgical success; SF: surgical failure; AS: audiological success; AF: audiological failure; SD: standard deviation, AC th: air-conduction threshold 


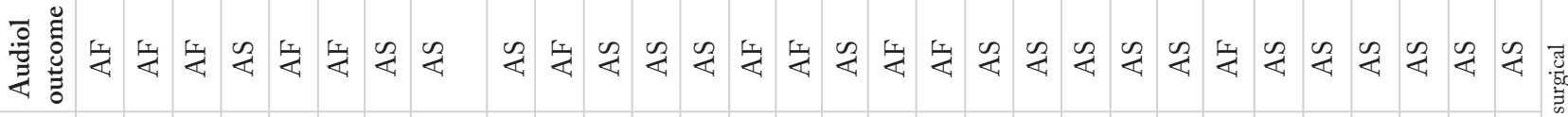

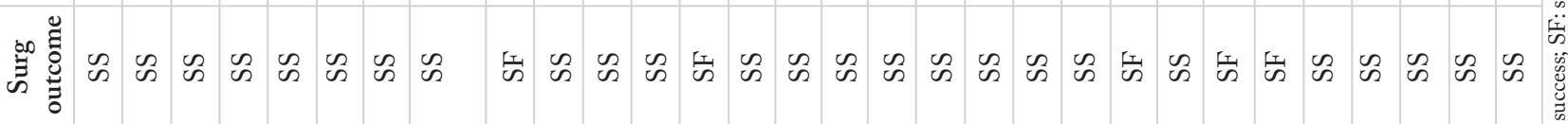

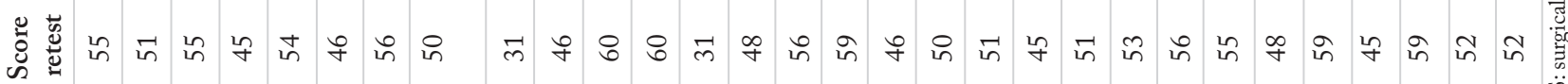

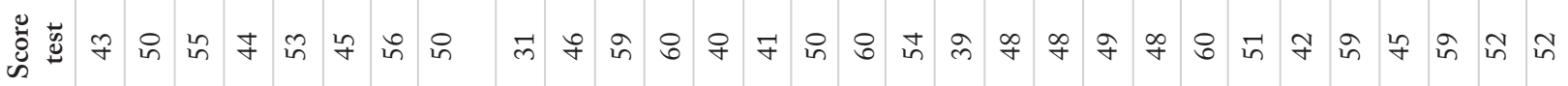

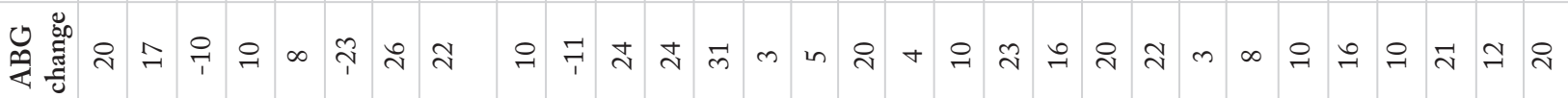

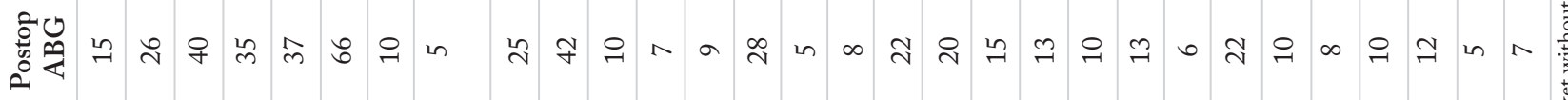

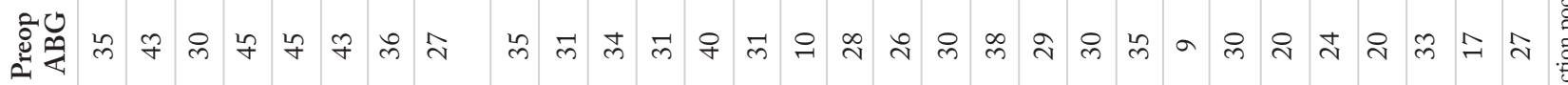

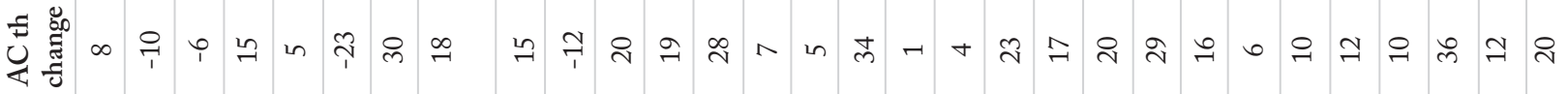

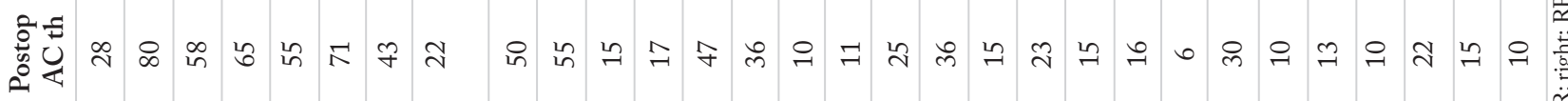

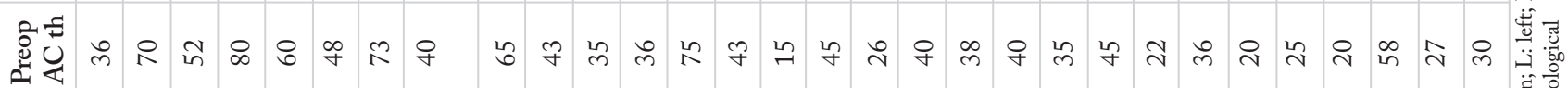

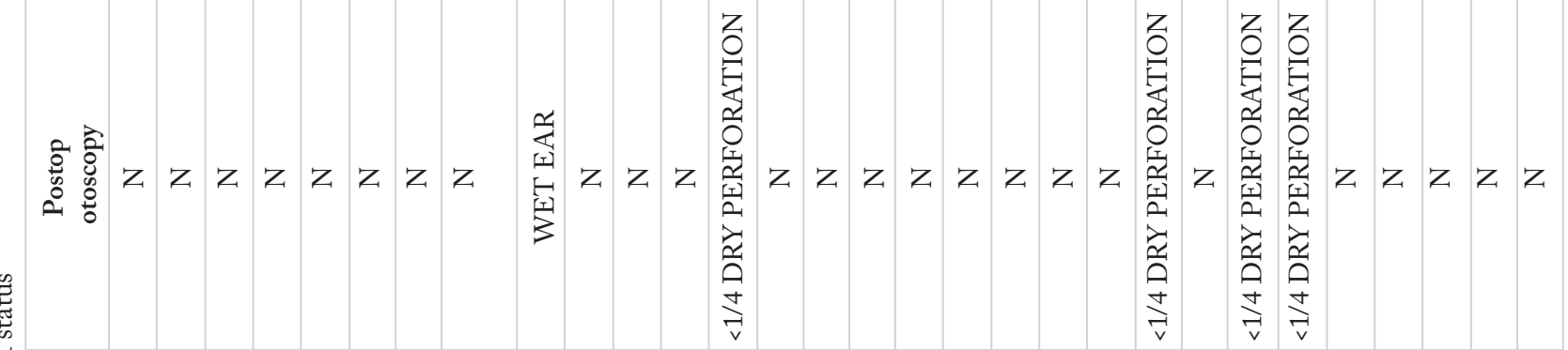

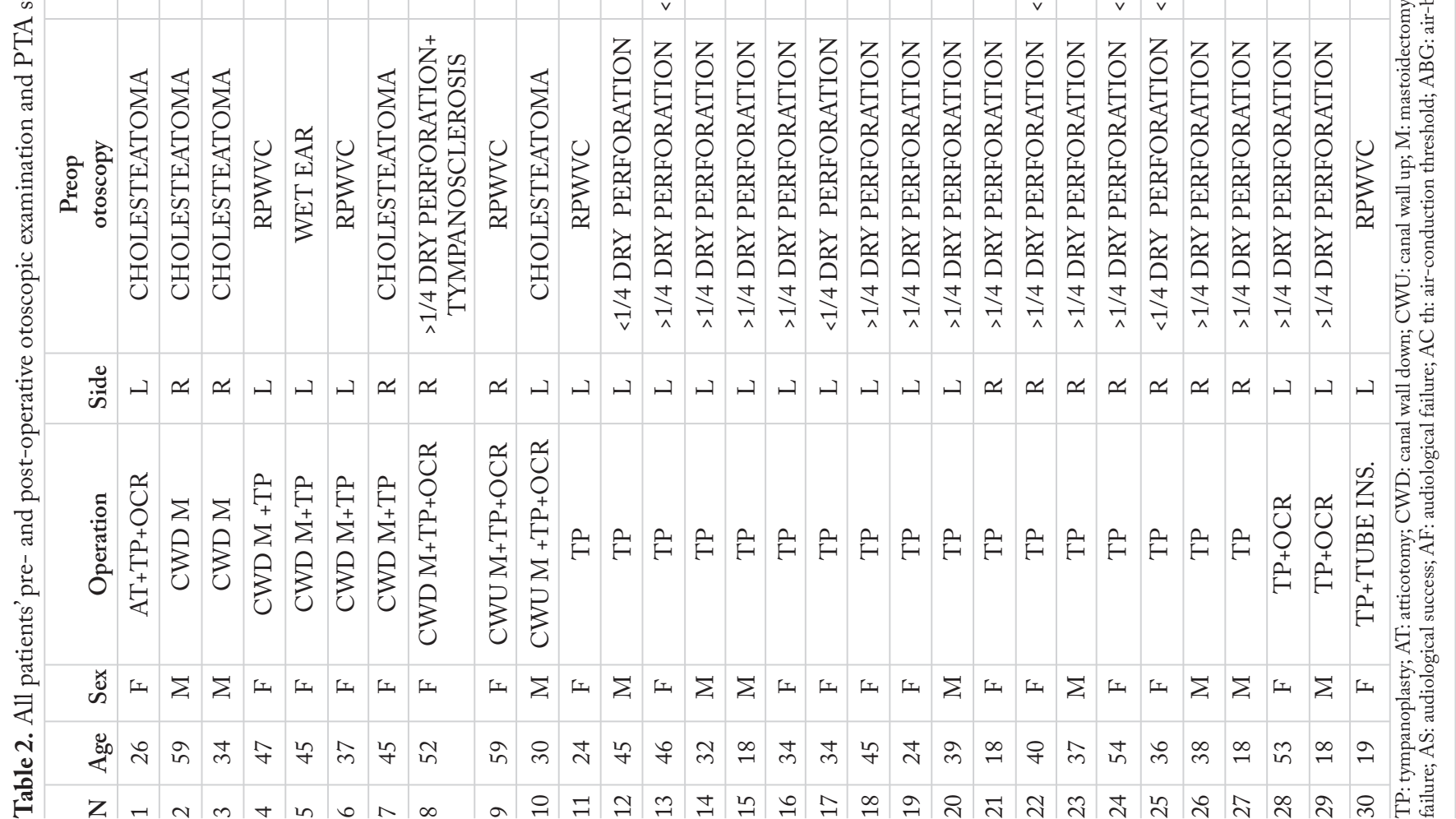


Table 3. Factor loading coefficients

\begin{tabular}{l|c|c|c|c}
\hline \multirow{2}{*}{$\begin{array}{l}\text { COMBI } \\
\text { question }\end{array}$} & $\begin{array}{c}|c| \\
\text { Factor (Impact } \\
\text { on patient's } \\
\text { life) }\end{array}$ & $\begin{array}{c}2 \\
\text { (Hearing } \\
\text { status) }\end{array}$ & $\begin{array}{c}\text { (Ear } \\
\text { status) }\end{array}$ & PC \\
\hline 1 & & & 0.909 & 0.900 \\
\hline 2 & & 0.718 & 0.362 & 0.735 \\
\hline 3 & & 0.629 & & 0.656 \\
\hline 4 & 0.788 & & 0.534 \\
\hline 5 & & & 0.778 & 0.716 \\
\hline 6 & 0.581 & 0.427 & & 0.763 \\
\hline 7 & 0.704 & & & 0.562 \\
\hline 8 & 0.863 & & & 0.523 \\
\hline 10 & 0.845 & & & 0.785 \\
\hline 11 & 0.614 & 0.386 & 0.369 & 0.662 \\
\hline 12 & & & & \\
\hline
\end{tabular}

PC: principal component analysis

Pearson's correlation between the total score of first test and the total score of the retest was calculated as $r=0.810$ at a significance level of 0.01 . This shows that the test and retest scores were correlated; hence, test-retest reliability was considered high.

The KMO measure of sample adequacy showed a ratio of 0.550 with a significance of less than 0.001 using Bartlett's test of sphericity. Thus, sample adequacy was considered sufficient to run factor analysis. Factor analysis using principal component extraction with varimax rotation produced a three-factor solution that explained $70.2 \%$ of the variances. Factor loading coefficients were higher than 0.5 for all items, which show the correlation between an individual item and its underlying factor (Table 3).

\section{Discussion}

This study is the first to validate the Turkish adaptation of the recognized and validated English HRQoL questionnaire that was developed for COM patients undergoing ear surgery. To date, the questionnaire has been translated only into Dutch (11).

Although patients with COM have similar pathophysiologic causes, the effects of the disease on patients show great variety. While some patients are asymptomatic and the condition is identified during routine check-up, in others the disease can severely deteriorate QoL. Hence, several questionnaires that evaluate HRQoL in COM patients have been developed. These questionnaires, however, determine the need for treatment and the expected benefits from an intervention. Patient-reported outcome measures mostly evaluate the impact of the intervention on patient's life. The Glasgow Benefit Index is a commonly used dynamic assessment tool for otolaryngology surgeries, is, however, not specific to ear surgery (12). Therefore, the COMBI questionnaire was created to combine HRQoL and patient-reported outcome measures for COM.
In our prospective study, the patients were divided into two different groups twice according to their surgical and hearing outcomes. By doing so, our main goal was to validate the Turkish version of the COMBI whilst showing the differences in the COMBI scores of the success and the failure groups. The average score of the SS group was $51.08 \pm 6.36$. This average score was higher than that of the SF group, which was $42.40 \pm 7.77$, and statistically significant $(\mathrm{p}<0.05)$. However, patients 22 and 24 , i.e., 2 of the 5 patients in the SF group, had a total score of 48 and 51, respectively. Their total scores of the questionnaire were close to the average score of the SS group. These unexpectedly high scores may be explained in two ways. Patient 22 showed $29 \mathrm{~dB}$ improvement in $\mathrm{AC}$ threshold and $\mathrm{ABG}$ after surgery. Whereas the patient's tympanic membrane perforation remained after the surgery, the size of the perforation had decreased sufficiently enough to prevent symptoms of recurrent drainage. Patient 24 was the only one included in both the SF and the $\mathrm{AF}$ groups. The patient also had a minimal failure and ear symptoms were recovered after surgery. Her hearing outcome was also considered as failure because she showed only $6 \mathrm{~dB}$ decrease in $\mathrm{AC}$ threshold and $8 \mathrm{~dB}$ in ABG. Nevertheless, some individuals can discriminate even minor differences in hearing and can score higher than expected, as was the case of this patient. These kinds of diversities bring forth the importance of patient-based assessment tools.

No statistically significant difference was found between the average scores of the AF and the AS groups. Ten of the $11 \mathrm{pa}^{-}$ tients in the AF group had successful surgical outcomes. All 11 patients had neither a draining ear nor bad smell in the operated ear. Only three of the 11 patients showed deterioration in AC threshold. The remaining eight patients had a decrease of less than $10 \mathrm{~dB}$ in their AC threshold. All of these causes can explain why the groups (AS and AF) had similar scores.

These results may indicate that COM patients are mostly satisfied with the surgical outcomes. Assessing the results of a procedure only by objective methods may lead to the under- or over-assessment of subjective (patient's point of view) outcomes. Therefore, it is very important to integrate self-assessment $\mathrm{QoL}$ questionnaires, such as otoscopic examination and PTA status into objective tools, as we have done in our study.

We also calculated a reliable Cronbach's alpha value of 0.862 , which is similar to that of the original English study (0.911) (6). Pearson's correlation $r$ value $(0.810)$ demonstrated that test and retest reliability was consistent. Two patients (numbers 1 and 18), however, showed more than 10 points of difference in their COMBI scores for test and retest reliability. This may be due to test-retest variability.

Furthermore, factor analysis showed a three-factor solution that explained $70.2 \%$ of the variances in our study, which is similar to that of the original study. Phillips et al. (6) named these factors as changes in hearing, in ear symptoms and in healthcare use. In their study, questions 3, 4, 8 and 9 were loaded onto factor 1 about hearing which assess the changes in 
hearing at home and in a group, in problems when performing daily activities, and in fear of water exposure, respectively. Questions 1, 2, 5, 6 were loaded onto factor 2 (ear symptoms) corresponding to the changes in ear discharge, bad smell in ear, ear discomfort, and dizziness, respectively. Questions about the changes in general practitioner attendance (Question 10) and in requirement for drugs (Question 11) were loaded onto factor 3 (healthcare use).

In our study, questions $8,9,10,11,12$ were loaded onto factor 1 which is about the effects on patient life, and questions 3, 4, 5, 7 were loaded onto factor 2 (hearing status). Questions 1, 2, 6 were loaded onto factor 3 (ear status).

\section{Conclusion}

Our study demonstrated the Turkish version of the COMBI questionnaire (appendix) to be a reliable and valid test for assessing QoL after ear surgery in patients with COM. It is appropriate to be used with objective assessment tools to better understand the outcomes of ear surgeries and their effects on the QoL of Turkish speaking patients.

While objective assessment tools should be used to show the benefits of the surgeries performed, self-assessment tools like QoL questionnaires should be added in order to better estimate the changes in the QoL of patients. Self-assessment tools can help doctors and healthcare providers to understand patients' feelings and thoughts about the intervention they have undergone.

Ethics Committee Approval: Ethics committee approval was received for this study from the Scientific Research Ethics Committee of İstanbul University School of Medicine (2019/50).

Informed Consent: Written informed consent was obtained from the patients who participated in this study.

Peer-review: Externally peer-reviewed.

Author Contributions: Concept - H.K., C.D., M.Ç., B.P., V.T., K.S.O.; Design - H.K., C.D., M.Ç., B.P., V.T., K.S.O.; Supervision - H.K., C.D., M.Ç., B.P., V.T., K.S.O.; Fundings - B.P., V.T., K.S.O.; Data Collection and/or Processing - H.K., C.D., B.P.; Analysis and/ or Interpretation - H.K., B.P., C.D.; Literature Review - H.K., B.P.,
C.D.; Writing - H.K., C.D., M.Ç., B.P., V.T., K.S.O.; Critical Reviews - H.K., C.D., M.Ç., B.P., V.T., K.S.O.

Conflict of Interest: The authors have no conflicts of interest to declare.

Financial Disclosure: The authors declared that this study has received no financial support.

\section{References}

1. Monasta L, Ronfani L, Marchetti F, Montico M, Vecchi Brumatti L, Bavcar A, et al. Burden of disease caused by otitis media: Systematic review and global estimates. PLoS ONE 2012; 7: e36226. [Crossref]

2. Black N. Patient reported outcome measures could help transform healthcare. BMJ 2013; 346: 167. [Crossref]

3. Baumann I, Kurpiers B, Plinkert PK, Praetorius M. [Development and validation of the Chronic Otitis Media Outcome Test 15 (COMOT-15). Measurement of health-related quality of life in patients with chronic otitis media]. HNO 2009; 57: 889-95. [Crossref]

4. Vlastos IM, Kandiloros D, Manolopoulos L, Ferekidis E, Yiotakis I. Quality of life in children with chronic suppurative otitis media with or without cholesteatoma. Int J Pediatr Otorhinolaryngol 2009; 73: 363-9. [Crossref]

5. Phillips JS, Haggard M, Yung M. A new health-related quality of life measure for active chronic otitis media (COMQ-12): Development and initial validation. Otol Neurotol 2014; 35: 454-8. [Crossref]

6. Phillips JS, Haggard M, Spencer H, Yung M. The Chronic Otitis Media Benefit Inventory (COMBI): Development and validation of a dynamic quality of life questionnaire for chronic ear disease. Otol Neurotol 2017; 38: 701-7. [Crossref]

7. Doruk C, Çelik M, Kara H, Polat B, Güldiken Y, Orhan KS. Turkish translation and validation of Chronic Otitis Media Questionnaire-12. Turk Arch Otorhinolaryngol 2019; 57: 24-9. [Crossref]

8. Tavakol M, Dennick R. Making sense of Cronbach's alpha. Int J Med Educ 2011; 2: 53-5. [Crossref]

9. Mukaka MM. Statistics corner: A guide to appropriate use of correlation coefficient in medical research. Malawi Med J 2012; 24: 69-71.

10. Field A. Discovering Statistics Using SPSS. 3rd ed. London: Sage Publications; 2009.

11. De Greve G, van Dinther J, Maryn Y, Vanspauwen R, Zarowski A, Offeciers E. Validity and test-retest reliability of the Dutch version of the Chronic Otitis Media Benefit Inventory. J Int Adv Otol. 2019; 15: 34-7. [Crossref]

12. Robinson K, Gatehouse S, Browning GG. Measuring patient benefit from otorhinolaryngological surgery and therapy. Ann Otol Rhinol Laryngol 1996; 105: 415-22. [Crossref] 


\section{Appendix (Turkish version of COMBI Questionnaire)}

\section{Kronik Orta Kulak İltihabı Fayda Envanteri}

Bu anketin amacı, size uygulanan kulak ameliyatından veya başka bir girişimden sonra kulak problemlerinizin nasıl etkilendiğini saptamaktır.

Lütfen aşağıdaki her bir soruyu dikkatlice düşünerek cevaplayınız ve uygun kutuya işaret koyunuz.

Herhangi doğru veya yanlış bir cevap yoktur; fakat ilgili kutulara işaret koymadan önce lütfen her soruyu dikkatlice düşününüz. Anketi doldurmayı tamamladığınızda, lütfen bütün sorulara tek bir cevap verdiğinizi kontrol ediniz. Eğer anketi doldurmakta zorlanırsanız yardım isteyiniz.

\section{Semptom şiddeti:}

1. Ameliyatınızdan itibaren kulak akıntınız arttı mı azaldı mı?

\begin{tabular}{|c|c|c|c|c|}
\hline $\mathbf{5}$ & $\mathbf{4}$ & $\mathbf{3}$ & $\mathbf{2}$ & $\mathbf{1}$ \\
\hline Çok daha iyi & Biraz daha iyi & Değiş̧iklik yok & Biraz daha kötü & Çok daha kötü \\
\hline
\end{tabular}

2. Ameliyatınızdan itibaren kulaktan gelen kokuyu nasıl tarif edersiniz? Kulağınızdan gelen koku arttı mı azaldı mı?

\begin{tabular}{|c|c|c|c|c|}
\hline $\mathbf{5}$ & $\mathbf{4}$ & $\mathbf{3}$ & $\mathbf{2}$ & $\mathbf{1}$ \\
\hline Çok daha iyi & Biraz daha iyi & Değişiklik yok & Biraz daha kötü & Çok daha kötü \\
\hline
\end{tabular}

3. Ameliyatınızdan itibaren evdeki işitme düzeyiniz (örneğin televizyonun veya radyonun sesini açma ihtiyacı) arttı mı azaldı mı?

\begin{tabular}{|c|c|c|c|c|}
\hline $\mathbf{5}$ & $\mathbf{4}$ & $\mathbf{3}$ & $\mathbf{2}$ & $\mathbf{1}$ \\
\hline Çok daba iyi & Biraz daha iyi & Değ işiklik yok & Biraz daha kötü & Çok daha kötü \\
\hline
\end{tabular}

4. Ameliyatınızdan itibaren grup içerisindeki (ya da sesli ortamlarda) diğer insanları duymanız arttı mı azaldı mı?

\begin{tabular}{|c|c|c|c|c|}
\hline $\mathbf{5}$ & $\mathbf{4}$ & $\mathbf{3}$ & $\mathbf{2}$ & $\mathbf{1}$ \\
\hline Çok daha iyi & Biraz daha iyi & Değişiklik yok & Biraz daha kötü & Çok daha kötü \\
\hline
\end{tabular}

5. Ameliyatınızdan itibaren kulak içinde ya da etrafında rahatsızlık hissiniz arttı mı azaldı mı?

\begin{tabular}{|c|c|c|c|c|}
\hline $\mathbf{5}$ & $\mathbf{4}$ & $\mathbf{3}$ & $\mathbf{2}$ & $\mathbf{1}$ \\
\hline Çok daba iyi & Biraz daha iyi & Değişiklik yok & Biraz daha kötü & Çok daha kötü \\
\hline
\end{tabular}

6. Ameliyatınızdan itibaren sersemlik hissiniz ya da denge kaybınız arttı mı azaldı mı?

\begin{tabular}{|c|c|c|c|c|}
\hline $\mathbf{5}$ & $\mathbf{4}$ & $\mathbf{3}$ & $\mathbf{2}$ & $\mathbf{1}$ \\
\hline Çok daha iyi & Biraz daha iyi & Değişiklik yok & Biraz daha kötü & Çok daha kötü \\
\hline
\end{tabular}

7. Ameliyatınızdan itibaren çınlamanız ya da kulağınızdan gelen sesler arttı mı azaldı mı?

\begin{tabular}{|c|c|c|c|c|}
\hline $\mathbf{5}$ & $\mathbf{4}$ & $\mathbf{3}$ & $\mathbf{2}$ & $\mathbf{1}$ \\
\hline Çok daba iyi & Biraz daha iyi & Değişiklik yok & Biraz daha kötü & Çok daha kötü \\
\hline
\end{tabular}


Kara et al.

Turkish Translation of COMBI

\section{Yaşam tarzı, iş ve sağlık hizmetlerine etkisi}

8. Evde veya iş yerindeki günlük aktiviteleriniz açısından ameliyatınızdan beri daha çok mu problem yaşadınız daha az mı?

\begin{tabular}{|c|c|c|c|c|}
\hline $\mathbf{1}$ & $\mathbf{2}$ & $\mathbf{3}$ & $\mathbf{4}$ & $\mathbf{5}$ \\
\hline $\begin{array}{c}\text { Aktiviteleri gerçekleş- } \\
\text { tirirken çok daba fazla } \\
\text { problem yaşıyorum }\end{array}$ & $\begin{array}{c}\text { Aktiviteleri gerçekleşti- } \\
\text { rirken biraz daha fazla } \\
\text { problem yaşıyorum }\end{array}$ & Değişiklik yok & Aktiviteleri gerçekleş- & Aktiviteleri gerçekleş- \\
tirirken biraz daha az & tirirken çok daha az \\
problem yaşıyorum & & & problem yaşıyorum \\
\hline
\end{tabular}

9. İstediğiniz gibi duş ya da banyo yapabilmeniz açısından değerlendirdiğinizde ameliyatınızdan beri kulağınızın enfeksiyon kapmasından daha çok mu korku duyuyorsunuz daha az mı?

\begin{tabular}{|c|c|c|c|c|}
\hline $\mathbf{1}$ & $\mathbf{2}$ & $\mathbf{3}$ & $\mathbf{4}$ & $\mathbf{5}$ \\
\hline $\begin{array}{c}\text { Kulağım ıslanacak diye } \\
\text { çok daha fazla korkuyo- } \\
\text { rum }\end{array}$ & $\begin{array}{c}\text { Kulağım ıslanacak diye } \\
\text { biraz daha fazla korku- } \\
\text { yorum }\end{array}$ & Değişiklik yok & $\begin{array}{c}\text { Kulağım ıslanacak diye } \\
\text { biraz daba az korkuyo- } \\
\text { rum }\end{array}$ & $\begin{array}{c}\text { Kulağım ıslanacak diye } \\
\text { çok daha az korkuyorum }\end{array}$ \\
\hline
\end{tabular}

10. Ameliyatınızdan itibaren kulak problemleriniz açısından doktorunuza daha sık mı başvuruyorsunuz daha az mı?

\begin{tabular}{|c|c|c|c|c|}
\hline $\mathbf{1}$ & $\mathbf{2}$ & $\mathbf{3}$ & $\mathbf{4}$ & $\mathbf{5}$ \\
\hline Çok dahasık & Biraz daha sık & Değişiklik yok & Biraz daha az & Cok daha az \\
\hline
\end{tabular}

11. Ameliyatınızdan itibaren kulak probleminiz nedeniyle ilaç kullanma gereksiniminizin sıklığı (hap ya da damla) arttı mı azaldı mı?

\begin{tabular}{|c|c|c|c|c|}
\hline $\mathbf{1}$ & $\mathbf{2}$ & $\mathbf{3}$ & $\mathbf{4}$ & $\mathbf{5}$ \\
\hline Çok dahasık & Biraz daha sık & Değişiklik yok & Biraz daha az & Çok daha az \\
\hline
\end{tabular}

\section{Genel:}

12. Ameliyatınızdan itibaren kulak probleminizin sizi bunaltması arttı mı azaldı mı?

\begin{tabular}{|c|c|c|c|c|}
\hline $\mathbf{1}$ & $\mathbf{2}$ & $\mathbf{3}$ & $\mathbf{4}$ & $\mathbf{5}$ \\
\hline $\begin{array}{c}\text { Eskiye göre çok daba } \\
\text { fazla }\end{array}$ & $\begin{array}{c}\text { Eskiye göre biraz daba } \\
\text { fazla }\end{array}$ & Değişiklik yok & Eskiye göre biraz daha az & Eskiye göre çok daha az \\
\hline
\end{tabular}

